\title{
St. Anne’s collegiate in Kraków as a geotouristic site
}

\author{
Kolegiata św. Anny w Krakowie jako obiekt geoturystyczny
}

\author{
Monika Florczyk, Anna Smoleńska \\ AGH University of Science and Technology, Faculty of Geology, Geophysics and Environment Protection, \\ Department of Economic and Mining Geology, al. A. Mickiewicza 30, 30-059 Kraków; \\ e-mail:m_florczyk@op.pl; smolensk@geol.agh.edu.pl
}
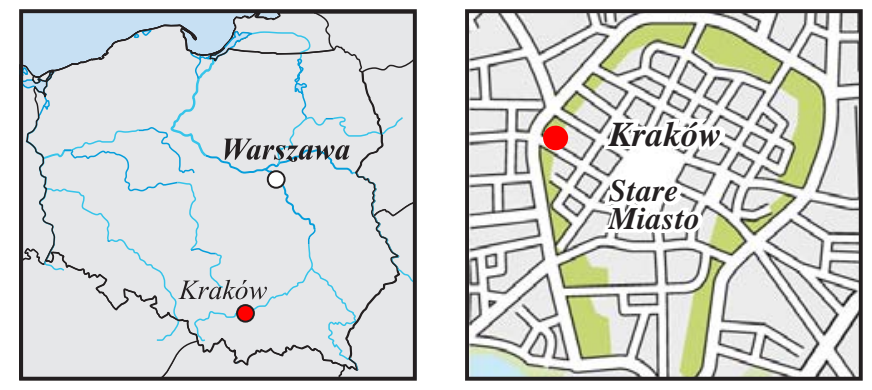

Abstract: The authors aim at drawing the attention of tourist not only to the history and architecture of St. Anne's collegiate church in Kraków, one of the most beautiful Baroque structures in Poland. The particular aspect they focus on refers to the decorative valour of the stones, which in large numbers and an attractive manner have been used inside and outside the church. As an addition to the description of the rock types and their varieties used, the places of quarrying the respective stones have been indicated for those interested in geology.

Key words: Kraków, St. Anne’s collegiate, stone

Treść: Celem niniejszego artykułu jest zainteresowanie turystów historia i architektura najpiękniejszej budowli barokowej w Polsce, która jest kolegiata św. Anny w Krakowie. W sposób szczególny zwrócono uwagę na walory dekoracyjne kamieni, które licznie i ciekawie zostały w niej zastosowane. Przedstawiono różne rodzaje i odmiany skat występujace wewnątrz i na zewnątrz tej budowli sakralnej. Dla zainteresowanych geologia wskazano miejsca pochodzenia materiatu kamiennego.

Stowa kluczowe: Kraków, kolegiata św. Anny, kamień

\section{Introduction}

Kraków is a town of an exceptional significance in the history of Poland, with a well preserved medieval layout, full of historic buildings, including those of special architectonic value. These reasons laid the grounds for including Kraków into the UNESCO World Heritage List. The sacral structures prevail over the secular ones among the historic buildings of Kraków. The edifices were erected of various building materials, initially of rocks available in the town proximity. Later, bricks were introduced, which supplanted rocks in the Gothic period. Rocks, however, remained an excellent material used in numerous finishing elements, architectonic details and in sculpture.

The collegiate church of St. Anne, associated with the Jagiellonian University and called an academic sanctuary by
Cardinal Karol Wojtyła, may be included in the more beautiful Baroque sacral structures in Kraków. It is located within the Quarter No. I (i.e. Old Town) at St. Anne's Street. In the 14th century the street was situated within the Jewish quarter, thus called Jewish Street. It runs from the Main Market to the small Jewish Gate (later known as St. Anne's Gate) in the city walls close to the Gunsmith Tower. The current street name was introduced at the end of the 15th century (Ormicka, 2003).

\section{Geomorphologic sketch of Kraków}

Kraków is situated in the south-eastern part of the Silesian-Cracow Monocline, within the Kraków Upland. The structure of the upland, developed as horsts separated by relatively narrow tectonic troughs, has shaped the town outline (Tyczyńska, 1976). Kraków was built on rocks of various ages. The oldest are Upper Jurassic limestones developed in the thick-bedded, platy and massive facies. The latter variety gives shape to the town morphology and crops out as diversified tors on valley slopes. The massive and the platy limestones are the main construction and decorative materials of the historic structures of Kraków.

\section{Some words on the collegiate and its history}

Today's church is the third structure standing on the site (Bukowski, 1903). The first was made of wood and burned in 1407. The second, made of stone or bricks, was erected during the reign of the King Władysław Jagiełło (construction started in the first quarter of the 15th century). The church, entrusted to the care of the Kraków Academy (currently the Jagiellonian University), was the place of a cult and also of observing religious ceremonies of the university. The third, larger church was built in the years 1689-1705 after pulling down the former one. It was designed by Tylman van Gameren, a Dutch architect residing at the court of Prince Stanisław Lubomirski. This architect belonged to the group of designers following the mature, classic Baroque in their designs and the church of St. Anne duly represents typical forms of this style (Rożek, 1995). They can be seen in the plan of the church, the outlook of the façade and the interior decoration (Klein, 1913). The façade overlooking St. Anne's Street is a wide elevation composed of three essential elements: 
a two-storey central part terminated by a tympanum and two, also two-storey towers dominated by huge columns and tremendous cornices, coexisting with the pilasters and pillars of massive proportions. Going inside and crossing the doorsill, we enter the collegiate with an exceptionally rich Baroque decor, expressed by numerous murals, paintings, sculptures and reliefs (Rożek, 2007). It is worthy of mentioning that Tylman van Gameren modelled initially his project on the San Carlo ai Catinari Church and finally patterned it on the San Andrea Della Valle Church (both in Rome). The differences between the St. Anne's Church and its Roman prototype consist in the two front towers added to the Cracovian church, and the rectangular wall terminating its chancel instead of a semi-circular chancel apse in the San Andrea's (Fig. 1). The remaining details of the layout and the inner

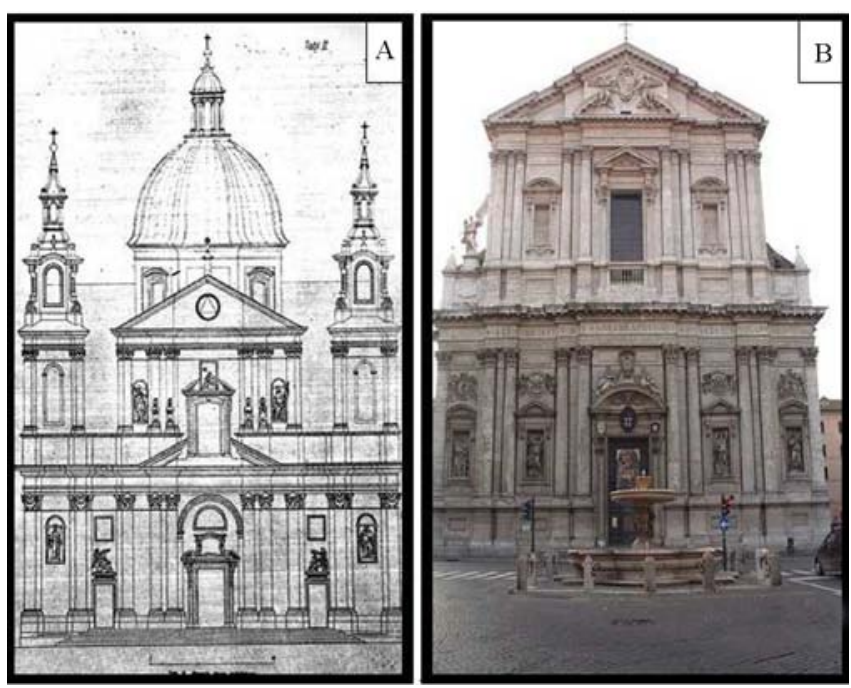

Fig. 1. The façades of the churches: A - St. Anne's (Gomoliszewski, 1957), B - St. Andrea's Della Valle (http://www.flickr.com) • Fasady kościołów: A - św. Anny (Gomoliszewski, 1957), B - św. Andrea Della Valle (http://www.flickr.com)

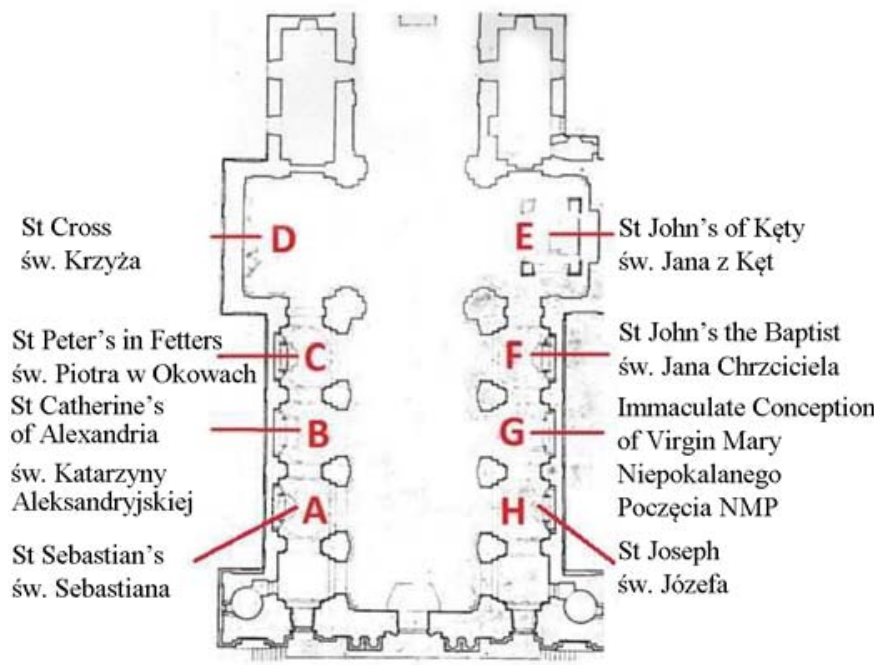

Fig. 2. The layout of St. Anne's Church (Gomoliszewski, 1957) with the chapel names added • Rzut poziomy kościoła św. Anny (Gomoliszewski, 1957) uzupełniony nazwami poszczególnych kaplic construction of the walls are the same in both church buildings (Klein, 1909).

The plan of the St. Anne's Church follows the Latin cross that is the symbol of Christian faith and, besides being a symbol, also carries an additional message in orientation of its beams. The shorter beam of the cross marks the unification of the people of the East and the West, whereas the longer beam is the sign of unification of the Heavens and Earth. The collegiate is a three-nave basilica with a transept. Its four-bay main nave is flanked from each side by a row of three interconnected chapels (Fig. 2), which together with the side narthexes make up the aisles (Mossakowski, 1965). Going down the left aisle, the chapels are devoted to St. Sebastian, St. Catherina of Alexandria, St. Peter in Fetters, and down the right aisle to St. Joseph, the Immaculate Conception of Virgin Mary and St. John the Baptist. The left end of the transept is taken by the Chapel of Adoration of the Holy Cross, while the right one by the confession (the altar-tomb) of St. John of Kęty. The crossing of the nave and the transept is covered by a huge cupola with the circular projection patterned after the cupola of the church of St. Peter and St. Paul in Kraków. The role of a supervising architect was played by Balthazar Fontana (Klein, 1909).

\section{Stones in St. Anne's Church}

As in each Baroque structure, stone makes an immanent part of the St. Anne's Church. It stresses the monumental character of the collegiate and, alongside numerous ornamental motifs, various sculptural compositions, reliefs and paintings, it enriches the unusual decor of its interior. It has also been used outside the church, among others as the material of stairs, columns, pilasters, portals, a plinth facing, a tympanum, window frames, epitaph plaques and also in church fencings. Stones also line the yard between the collegiate and other church buildings.

\section{Outer side of the church}

The stairs leading to the collegiate look magnificent, and their number results from a significant difference of about $1.1 \mathrm{~m}$ between the levels of the church and the street (Fig. 3). They were replaced twice and the current ones have been made of the Cretaceous blocky sandstone, coming probably from the Żerkowice deposit (Natkaniec-Nowak, Świgoń, 2004). Each of the eight levels of the stairs is $13.5 \mathrm{~cm}$ high and $30 \mathrm{~cm}$ wide. The lengths of the sandstone ashlars are different: 80, 85, 110 and $114 \mathrm{~cm}$.

The lowest stone part of the church is the plinth facing. It plays two roles: a construction one - strengthening the building, and an ornamental one - sticking out beyond the plane of the walls. The plinth is about $1.5 \mathrm{~m}$ high and runs along the full width of the nave projection, then it passes onto the surface of the towers. The plinth in the SE part is made of the ashlars of fine-grained Cretaceous sandstone (Fig. 3), whereas in the NW elevation is bipartite: in its lower part the 
Jurassic limestone was used and in the upper one the finegrained Cretaceous sandstone was applied (Fig. 4).

The next construction elements are columns and flat pilasters (Fig. 5). Two columns flank each side of the main entrance into the church. Each of their shafts is composed of three sandstone ashlars cut into shape. They rest on the profiled bases and are closed from the top by decorative capitals. The columns with the diameter $1.2 \mathrm{~m}$ are fifteen or so meters high, their bases $(1.2 \times 1.2 \mathrm{~m})$ are $1.5 \mathrm{~m}$ high. The columns have been made of sandstone, whereas their bases and the bases of the pilasters were cut of regularly worked, rectangular blocks of the Jurassic limestone.

The church has six pilasters. They are multiplied, i.e., made in the form of the so-called bundles in which the width of each next pilaster is shorter if compared with that of the preceding one. The pilasters are arranged as follows: four in the corners of two towers and two by the side entrances. The pilaster shafts are also fifteen or so meters high and $0.9 \mathrm{~m}$ wide.

Portals belong to more impressive architectonic elements of the façade (Fig. 6). Two on both sides of their outlook is magnified by the design, architectonic details, and also the kind of stone material used. There are three portals leading into the collegiate: the main one and the two side ones. The main portal is closed from the top by a plaque, which is surrounded by twisted fragments of the portal head (Majewski, 1993). The portal frames have profiled edges and extend up into the doorheads. Fifteen or so ashlars of the Jurassic limestone were used in constructing the portals and their sills. In the doorheads of the side portals the architect also placed pink Devonian limestones.

Over the main portal there is a tympanum in the shape of the equilateral triangle with the eye of Providence in its centre. The tympanum is topped by the cross standing on a rectangular base. The tympanum has been made of fifteen or so ashlars of Jurassic limestone and fine-grained sandstone.

The window frames in the front, south-western façade differ in their shapes. They are semi-circular over the main portal and square over the side portals. In each case they slightly protrude from the wall face. All the window frames are made of fine-grained sandstone.

Fig. 3. The SE façade of the church - the plinth made of the Istebna Sandstone ashlars, the stars cut of the Cretaceous Quader Sandstone, phot. M. Florczyk • Elewacja SE kościoła - cokół z ciosów piaskowca istebniańskiego, schody z kredowego piaskowca ciosowego, fot. M. Florczyk

Fig. 4. The NW façade of the church: A - the white Jurassic limestone, B - the Istebna Sandstone, C - limestone pavement, phot. M. Florczyk - Elewacja NW kościoła: A - biały wapień jurajski, $\mathrm{B}$ - piaskowiec istebniański, C - bruk wapienny, fot. M. Florczyk

Fig. 5. The columns and pilasters of the façade made of the Istebna Sandstone, while their bases of the Jurassic limestone ashlars, phot. M. Florczyk - Kolumny i pilastry fasady z piaskowca istebniańskiego, a bazy kolumn i pilastrów z ciosów wapienia jurajskiego, fot. M. Florczyk
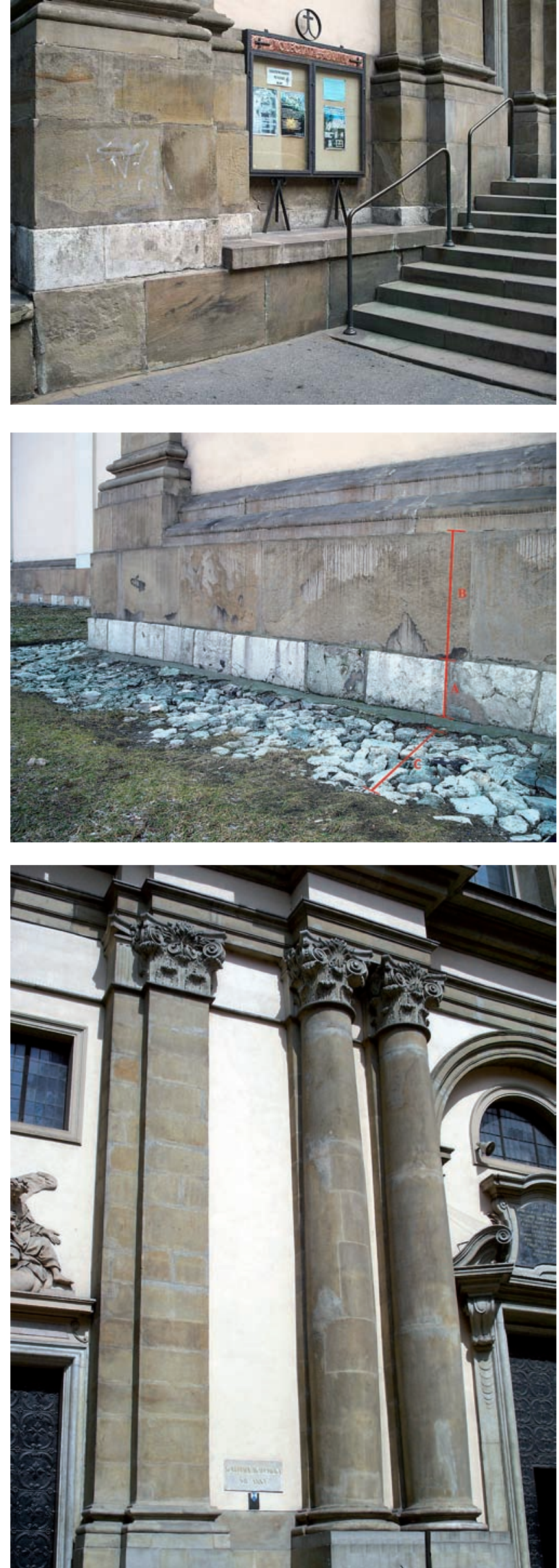


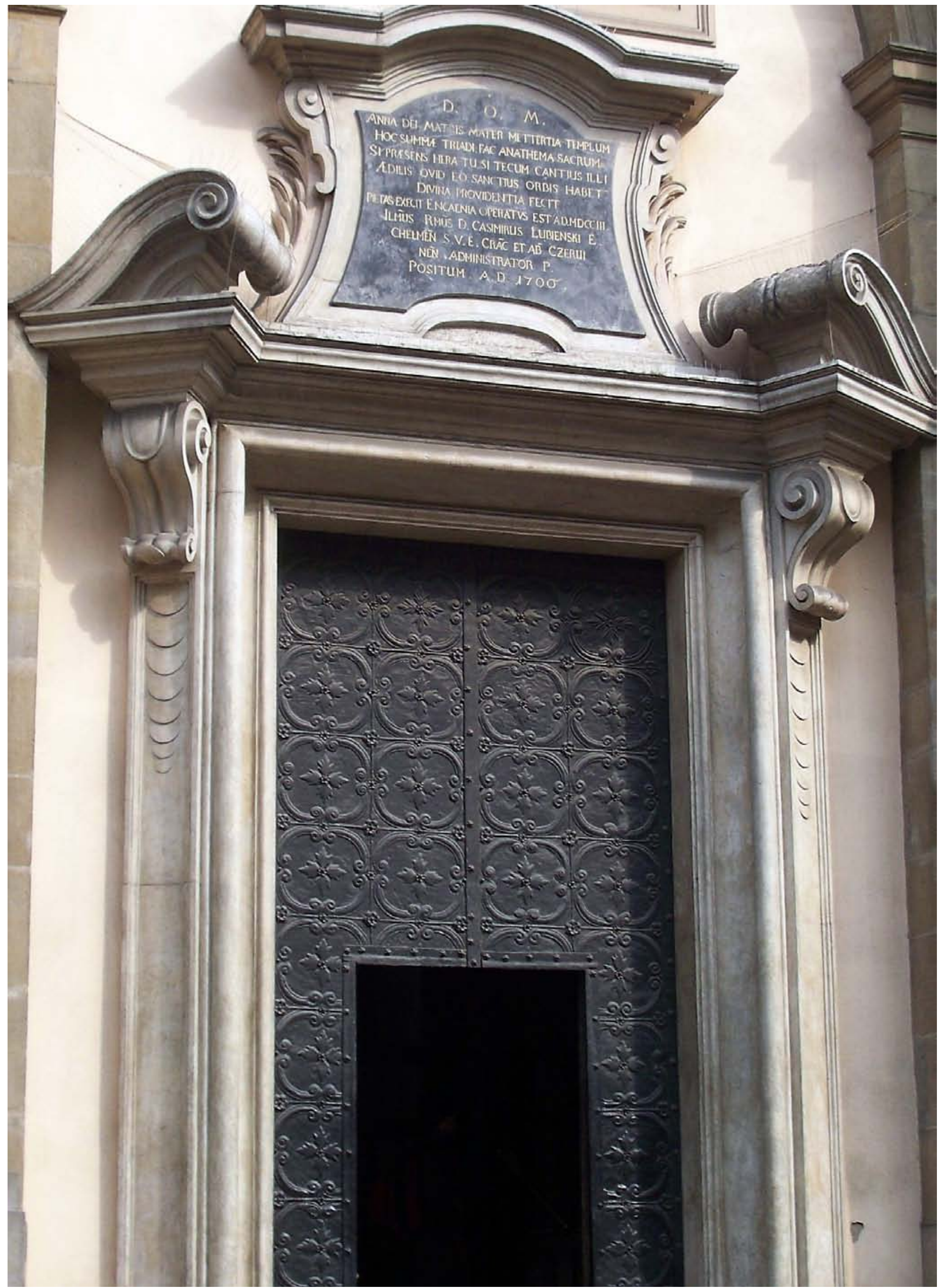

Fig. 6. The main portal made of the Jurassic limestone, phot. M. Florczyk • Portal główny z wapienia jurajskiego, fot. M. Florczyk 
St. Anne's collegiate in Kraków as a geotouristic site

\begin{tabular}{|c|c|c|c|}
\hline $\begin{array}{l}\text { A - chapel } \\
\text { St Sebastian's } \\
\text { kaplica } \\
\text { św. Sebastiana }\end{array}$ & $\begin{array}{l}\text { B - chapel } \\
\text { St Catherine's } \\
\text { of Alexandria } \\
\text { kaplica św. Katarzyny } \\
\text { Aleksandryjskiej }\end{array}$ & $\begin{array}{l}\text { C - chapel } \\
\text { St Peter's in Fetters } \\
\text { kaplica św. Piotra } \\
\text { w Okowach }\end{array}$ & $\begin{array}{l}\text { D - chapel } \\
\text { St Cross } \\
\text { kaplica } \\
\text { św. Krzyża }\end{array}$ \\
\hline
\end{tabular}

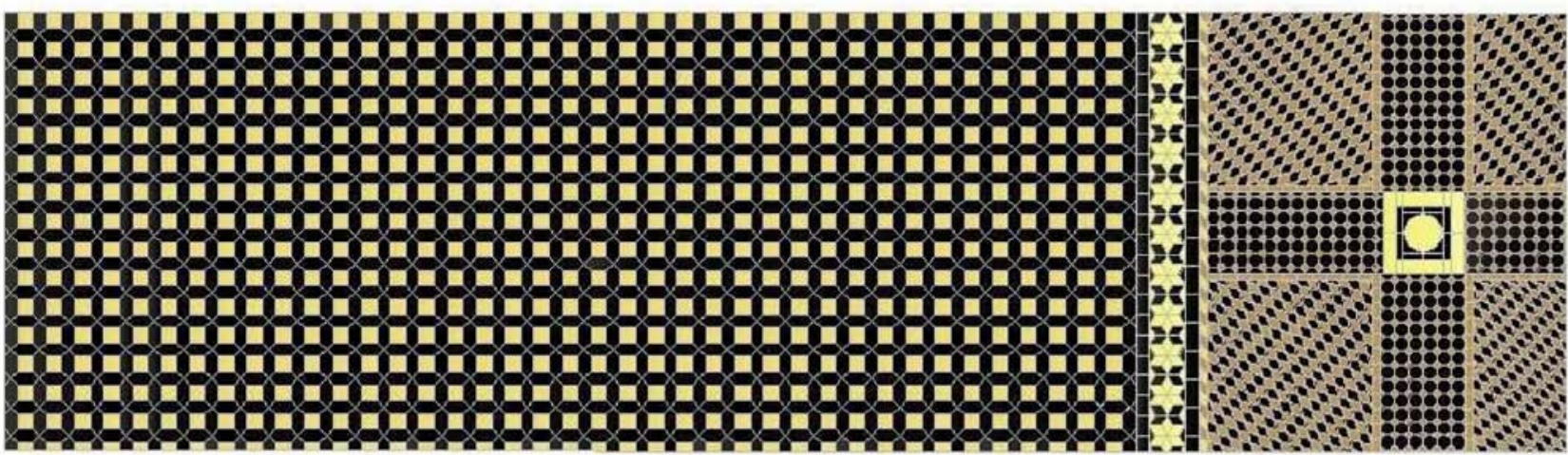

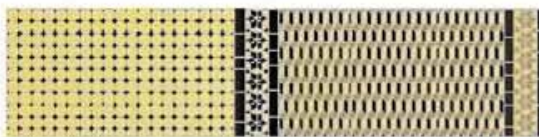

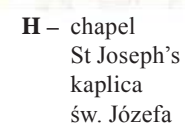

St Joseph'
kaplica

św. Józefa$$
\text { G }
$$

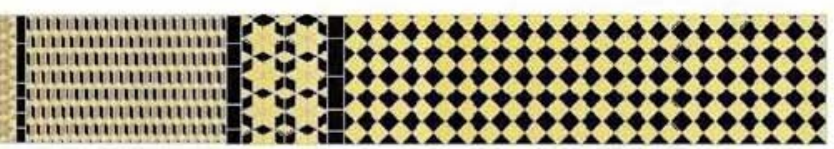

$\begin{aligned} & \text { F - } \text { chapel } \\ & \text { St John's Baptist } \\ & \text { kaplica św. Jana }\end{aligned}$

Chrzciciela

\author{
- creamy Jurrasic limestone • kremowy wapień jurajski \\ - black Dębnik limestone (devonian) • czarny wapień „dębnicki” (dewon) \\ - brown Bolechowice limestone (devonian) • brązowy wapień ,bolechowicki” (dewon) \\ - pink Chęciny limestone (devonian) • różowy wapień z Chęcin (dewon)
}

Fig. 7. The arrangement of the floor tile patterns in the main and side naves, (M. Florczyk) • Rozmieszczenie wzorów kamiennej posadzki w nawach głównej i bocznych (M. Florczyk)

Epitaph plaques, cut in the black Dębnik Limestone and attached into the walls of façade, also belong to the stone decorative elements.

A fencing flanks the SW and NE sides of the church building. The former row is composed of twenty guard posts, $100 \mathrm{~cm}$ high, linked with chains and placed on the $20 \times 45 \mathrm{~cm}$ bases (Fig. 4). The guard posts of the other row are shorter and without chains. A light yellow, fine-grained sandstone is the material used in making the posts.

The yard situated between the SE elevation of the church and the parochial buildings has a limestone pavement. Massive limestones represent the oldest rock material applied in paving streets and markets in Kraków at least since the 14th century (Rajchel, 2008). Broken, irregular blocks of Jurassic limestone, from 5 to $30 \mathrm{~cm}$ in diameter, have been placed as close as possibly to each other. Used over the years, they show signs of intensive wear and ovalisation, therefore such cobblestones have been called in Polish "feline-like heads".

\section{Church interior}

The stone-made elements inside the collegiate superbly unite all the church parts and give them a decorative trait. Proper selection of the stone types, differing in the rock texture, structure and colour, as well, has provided sets of unique elements, which - arranged in larger motifs - form the patterns with a gorgeous look. The stone decor of the interior includes the floor, epitaph plaques, decoration of the chapels and the monument to Nicolaus Copernicus.

The tile floor is the most outstanding stony element of the collegiate (Fig. 7). Its wonderful pattern was designed by Tylman van Gameren. When arranging it, he applied a trick based on an optical illusion and on using stone tiles of contrasting colours set against each other (Gomoliszewski, 1957). The floor pattern is set of simple geometrical figures cut of rocks with strikingly different colours, which results in certain elements appearing to be of different size than their counterparts. 

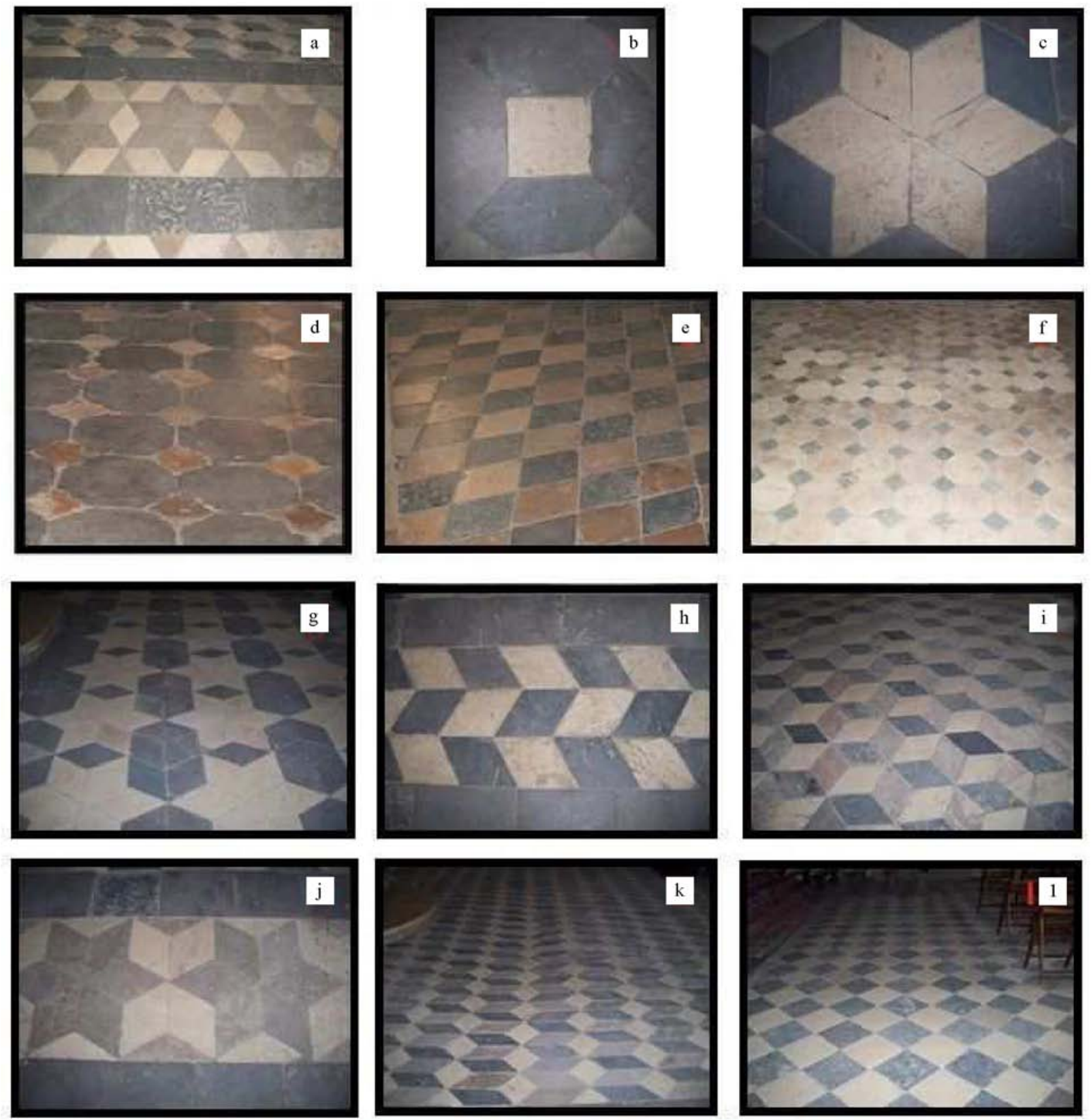

Fig. 8. The stone material used in the floor tile patterns, phot. M. Florczyk: a. A row of stone tiles made of the black Devonian limestone separating floor parts of various tile patterns; b. The main nave - the black Dębnik Limestone and the creamy Jurassic limestone; $\mathbf{c}$. The passage between the main nave and the transept - the creamy Jurassic limestone; $\mathbf{d}$. The transept - the black Dębnik Limestone and the brown Bolechowice Limestone; e. The transept part adjacent to the chancel - the black Dębnik Limestone and the brown Bolechowice Limestone; f. The narthex of the left aisle - the creamy Jurassic limestone and the black Dębnik Limestone; g. The chapel of St. Sebastian - the creamy Jurassic limestone and the black Dębnik Limestone; $\mathbf{h}$. The passage into the chapel of St. Catherine of Alexandria - the black Dębnik Limestone and the creamy Jurassic limestone; i. The chapel of St. Catherine of Alexandria - the black Dębnik Limestone, the pink limestones from Chęciny and the creamy Jurassic limestone; j. The passage into the chapel of St. Peter in Vinculi - the brown Bolechowice Limestone and the creamy Jurassic limestone; k. The chapel of St. Peter in Vinculi - the black Dębnik Limestone, the brown Bolechowice Limestone and the creamy Jurassic limestone; l. The chapel of the Holy Cross - the creamy Jurassic limestones and the black Dębnik Limestone

Materiał kamienny we wzorach posadzki, fot. M. Florczyk: a. Pas czarnego wapienia dębnickiego oddzielający posadzki o różnych wzorach; b. Nawa główna - czarny wapień dębnicki i kremowy wapień jurajski; c. Przejście między nawą główną a transeptem - kremowy wapień jurajski; d. Transept - czarny wapień dębnicki i brązowy wapień bolechowicki; e. Transept przy prezbiterium - czarny wapień dębnicki i brązowy wapień bolechowicki; f. Przedsionek lewej nawy bocznej - kremowy wapień jurajski i czarny wapień dębnicki; g. Kaplica św. Sebastiana - kremowy wapień jurajski i czarny wapień dębnicki; h. Przejście do kaplicy św. Katarzyny Aleksandryjskiej - czarny wapień dębnicki i kremowy wapień jurajski; i. Kaplica św. Katarzyny Aleksandryjskiej - czarny wapień dębnicki, różowy wapień z Chęcin i kremowy wapień jurajski; j. Przejście do kaplicy św. Piotra w Okowach - brązowy wapień bolechowicki i kremowy wapień jurajski; k. Kaplica św. Piotra w Okowach - czarny wapień dębnicki, brązowy wapień bolechowicki i kremowy wapień jurajski; l. Kaplica św. Krzyża - kremowy wapień jurajski i czarny wapień dębnicki 
In fact, all floor tiles are of the same size. The choice of the stone colour was the matter of the design, while the type of the stone was based on the presence of suitable rocks in the vicinity of Kraków.

Each pattern in the floor is separated by a row of slabs 20-30 cm wide and 25-70 cm long, made of the black Dębnik Limestone (Fig. 8a).

In the main nave with two rows of pillars, the pattern and the size of the stone tiles fit precisely the available space. Between the entrance and the transept the floor has the same pattern. Its single element is composed of five stone tiles: a central, $30 \times 30 \mathrm{~cm}$ square made of the creamy Jurassic limestone is surrounded by four, six-sided tiles of the black Dębnik Limestone (Fig. 8b). This part of the floor gives a unique spatial effect.

A row of stone stars separates the floor between the nave and the transept (Fig. 8c). The pattern is set of rhombuses with the diagonals 40 and $23 \mathrm{~cm}$. Each star is composed of six such tiles cut of creamy Jurassic limestone separated by the rectangles of the black Dębnik Limestone.

The transept itself has its floor main motif in the shape of the cross, arranged of the corner-truncated squares with the side length $28 \mathrm{~cm}$ made of the black Dębnik Limestone and of smaller squares with the side length $13 \mathrm{~cm}$ made of the brown Bolechowice Limestone (Fig. 8d). The centre of the cross is occupied by the circle, $80 \mathrm{~cm}$ in diameter, inscribed into the $160 \times 160 \mathrm{~cm}$ square. These elements were cut of the creamy Jurassic limestone and the spaces remaining in the corners were filled with the black Dębnik Limestone elements. The motif of the cross is bordered by a row of rectangles $(30 \times 15 \mathrm{~cm})$ cut of the brown Bolechowice Limestone and divides the floor into the four parts. Each of them is filled by rhombuses with the diagonals 38 and $22 \mathrm{~cm}$, made of the black Dębnik Limestone and the brown Bolechowice Limestone (Fig. 8e). Set alternatively aslant, they give the effect of a radial cross.

The floor of the left aisle begins in the narthex with a pattern of squares of the creamy Jurassic limestone with the side size $22.5 \mathrm{~cm}$, truncated in the corners, and smaller squares of the black Dębnik Limestone of side size $9 \mathrm{~cm}$ (Fig. 8f).

The floor of the passage into St. Sebastian's Chapel has been made of the black Dębnik Limestone. Within the chapel, the dominant pattern is composed of stars comprising rhombuses with the diagonals 40 and $23 \mathrm{~cm}$. Each star is made of six such elements cut of the creamy Jurassic limestone, separated by the black Dębnik Limestone tiles (Fig. 8g).

In the next passage into the St. Catherine's of Alexandria Chapel, there are rhombuses with the diagonals 31 and $18 \mathrm{~cm}$, which have been arranged in three rows. The tiles cut of the creamy Jurassic limestone and the black Dębnik Limestone form a herring-bone pattern (Fig. 8h). The floor of the chapel has been made of the black Dębnik Limestone, the pink Chęciny Limestone and the creamy Jurassic limestone, all cut into rhombuses with the diagonals 31 and $18 \mathrm{~cm}$. Due to the contrasting colours of the tiles, the designer has obtained an effect of spatially arranged squares (Fig. 8i).
The passage into the chapel of St. Peter's in Fetters is set of stars. Each star is composed of six rhombuses with the diagonals 31 and $18 \mathrm{~cm}$, cut of the brown Bolechowice Limestone, which are separated by the creamy Jurassic limestone (Fig. 8j). The floor of the chapel has the pattern including limestone parallelograms of various colours: brown Bolechowice Limestone and black Dębnik Limestone, completed by the squares of the creamy Jurassic limestone. Their combination gives an effect of spatially arranged rectangular prisms (Fig. 8k).

The floor in passage to the chapel of the Holy Cross in the transept follows the pattern used in the main nave: two rows of the stars cut of the creamy Jurassic limestone are separated by the black Dębnik Limestone. Within the chapel, the diamond-shaped floor pattern has been set of the alternating, $30 \times 30 \mathrm{~cm}$ squares of the black Dębnik Limestone and creamy Jurassic limestone (Fig. 81).

In the right end of the transept, i.e. in the Chapel of St. John of Kęty, the pattern and the stone material of its floor tiles are identical as in the Holy Cross Chapel. Coming back to the right side entrance, we can see that also the aisle floor is almost a mirror reflection of that in the left aisle. The passage into the St. John's the Baptist Chapel and the floor of this chapel are analogues of those described in the St. Peter's in Fetters. The next passage, i.e. that to the Chapel of the Immaculate Conception of the Virgin Mary, has the same floor pattern as that between the chapels of St. Catherine and St. Peter in Fetters.

In the Chapel of the Immaculate Conception of the Virgin Mary the pattern of floor tiles is identical as that applied in St. Catharine's of Alexandria chapel. A difference is in various colours of the stones used, i.e. the black Dębnik Limestone, the brown Bolechowice Limestone and the creamy Jurassic limestone. The next passage to the Chapel of St. Joseph parallels that between the chapels of St. John of Kęty and St. John the Baptist. The layout of the floor in the chapel of St. Joseph is the same as in the St. John's the Baptist one and the difference is in stone colours. The parallelograms have been made of the black Dębnik Limestone and the creamy Jurassic limestone, whereas the squares were cut of the brown Bolechowice Limestone. The last passage, i.e. to the right side entrance, follows the motif of stars, characteristic of this aisle. Maintaining the layout, the stones have been used in a reversed manner: rhombuses are cut of the black Dębnik Limestone and their separations - of the creamy Jurassic limestone. The floor of the right narthex is the same as that of the left one.

The whole interior is surrounded by a plinth $30 \mathrm{~cm}$ high made of the Jurassic limestone with visible fragments of cherts.

The epitaph tablets in the St. Anne's collegiate are situated on the side walls and on the pillars of the transept. The black Dębnik Limestone is the dominating material, accompanied in places by the Pińczów Limestone. The contemporary plaques have been made of a red granite (Fig. 9) and the Carrara Marble (Fig. 10) (Rożek, 2007).

Worthy of mention is the set of decorations in the chapel devoted to St. John of Kęty in the western section of the transept. Huge, spiralling columns. about $12 \mathrm{~m}$ high, fill us 
with awe and are pedestals of four figures of Saint Johns: St. John the Baptist, St. John the Evangelist, St. John Chrysostom and St. John of Damascus. The columns have been made of a Jurassic limestone, coming probably from the St. Salome's quarries (Bukowski, 1903).

Also attracting the attention is the monument to Nicolaus Copernicus, placed in the arcade of the left transept side. This is a homage paid by the University to its most famous student. The figure of the astronomer was carved in the years 1822 1823 by John Nepomuk Galli in the black Dębnik Limestone, following the design and using the funds of Father Sebastian Sierakowski (Adamczewski, 1992).

The stoups, placed next to the side entrances and in the narthex of the collegiate are the last elements of the decoration. Hanged on the walls, they resemble goblets in shape (Fig. 11). The stoups have been sculpted in the black Dębnik limestone: fossils and white calcite veins present in this rock underlie its ornamental values.

\section{Origin of the stone material}

The stones used as the construction and decoration materials of the collegiate represent prevalently Polish rocks. Only in two contemporary plaques the rock imports were used. The petrographic characteristics of the stones indicate that they were quarried from the deposits situated not far from Kraków.

Limestones and sandstones are major stone materials used in the construction and decoration of the church. The Devonian limestones, also known as the Dębnik "Marble", Bolechowice "Marble" or Różanka "Marble" have been used mainly as decorative stones. Information in the manuscript of Father Kracik (2003) localises Dębnik near Czerna as the site of origin of the black marble, thus, the stones must have been quarried there in one of the following pits: "Carmelite Quarry", "Grey Mount", "Cekierowa Mount", "Dungeon Marbles" or "Tumidajski's Quarry" (Zaręczny 1891, 1953). The "Bolechowice marble" comes from the Holy Cross Mts. area, and the best known sites of its quarrying are situated in Bolechowice, Szewce and Jaźwica villages, while many small pits occur also near Chęciny (Rajchel, 2005). The "Różanka marble", known also as the Chęciny or the Zelejowa Marble (Rajchel, 2005), is the oldest quarried variety of this rock. In the literature, it was described mainly as the marble of the Zelejowa Mt. Ridge. Similar rocks occur also in the vicinities of Miedzianka, Ołowianka, Zawada and Kowala villages (Czarnocki, 1958).

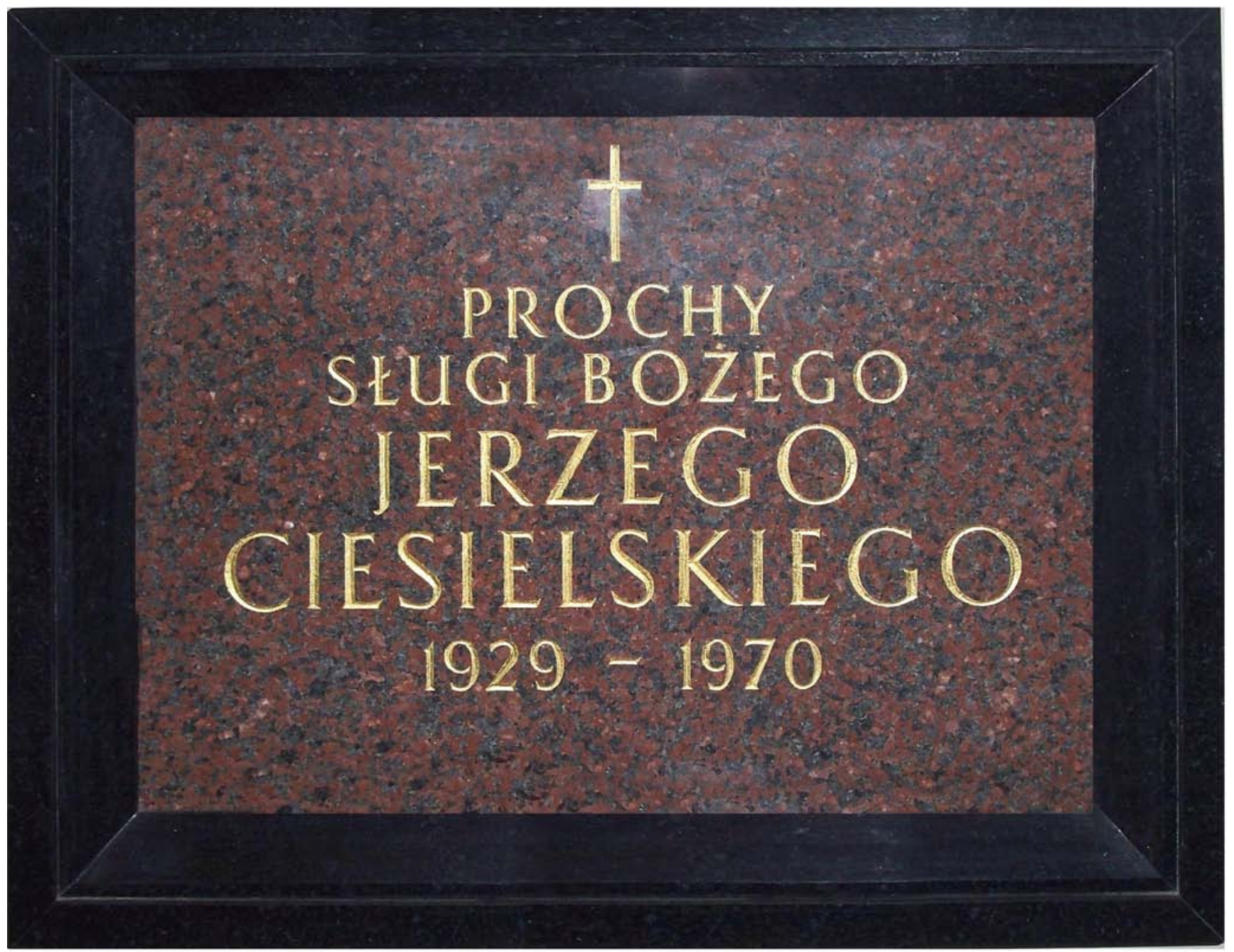

Fig. 9. The epitaph tablet made of the Capao Bonito granite from Brazil, phot. M. Florczyk • Tablica z czerwonego granitu Capao Bonito z Brazylii, fot. M. Florczyk 


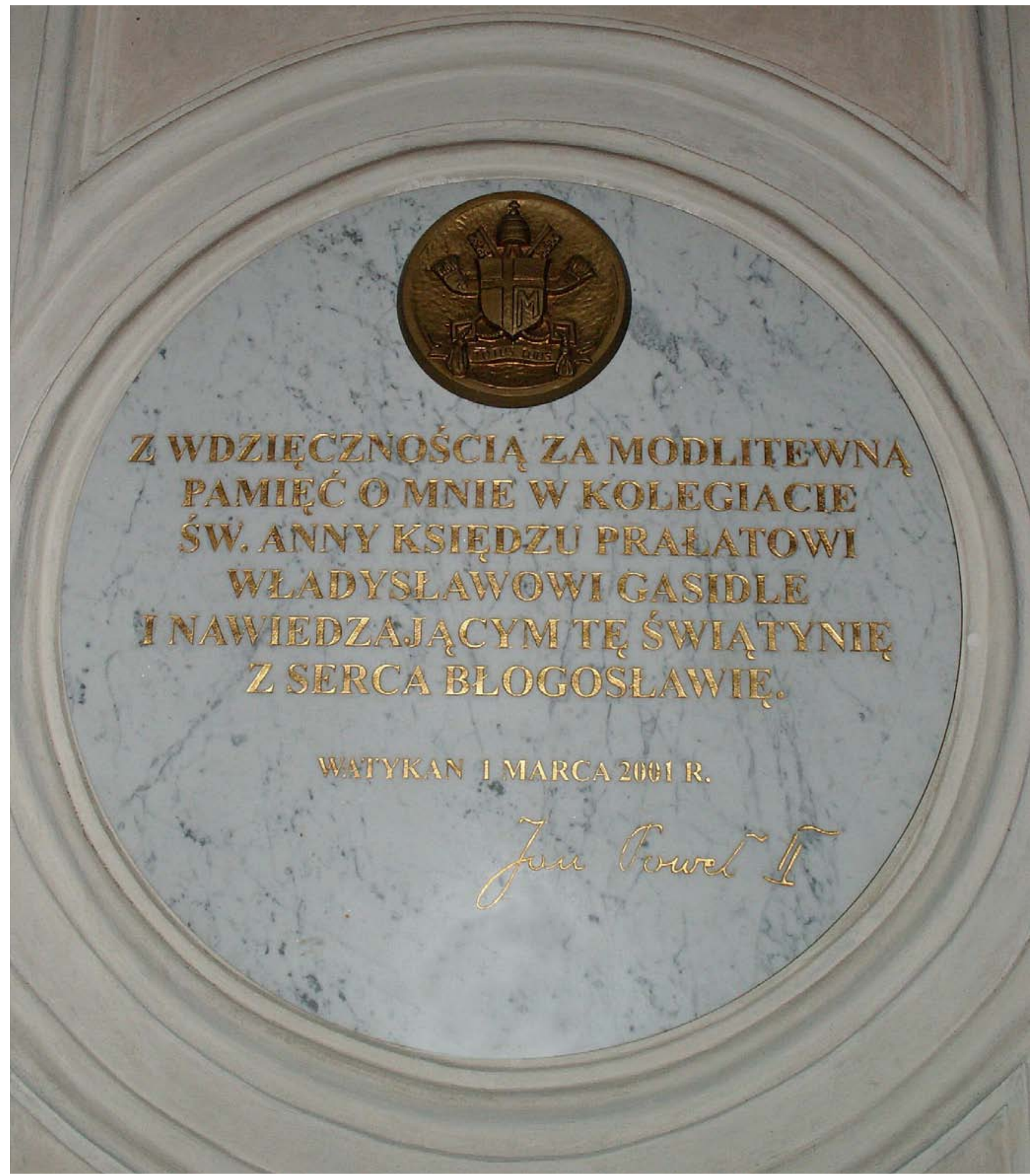

Fig. 10. The epitaph tablet made of the Bianco Carrara marble, phot. M. Florczyk • Tablica z białego marmuru Bianco Carrara, fot. M. Florczyk

The "Różanka marble" has its coloration closely resembling that of the Carboniferous "Paczółtowice Marble" localised near Kraków. Therefore, it has been the first supposition that the marble used in St. Anne's Church was brought rather from a quarry situated near Kraków, i.e., just from Paczółtowice. However, information contained in the "Building Record" of the church and mentioned in Father Kracik's paper (2003) points rather to the distant Chęciny area as the very site of quarrying the marble.

Another carbonate rock used in the collegiate is the Jurassic limestone. There are many outcrops of this rock with diversified bedding and textural patterns, therefore widely used in the architecture of the church. The rocks in question build the horst of the Wolski Small Forest, and also the hills 
of the Twardowski Tors and the Krzemionki Podgórskie where quarries still exist (Rajchel, 2005). The white, finedetrital variety used mainly in the pavement comes either from the quarry known as "Tetynka" or from the "Behind the Rail Track" quarry, known also as the "Liban's quarry", and localised beneath the Krakus Mound, respectively. The carbonate plinth inside the collegiate contains siliceous concretions, which implies that it was made of a massive or thick -bedded limestone variety. Such a limestone comes from the "Blessed Salome quarries" situated on the so-called Grodzisko Hill near Ojców (Holcer, Krajewski, 2001). The same material has been probably used in curving the spiral columns flanking the tomb of St. John of Kęty, and also the portals of the main entrance into the church. The next variety of limestones used in the portal sills is represented by rocks with characteristic darker spots identified as tuberoids. Such limestones occur in the Holy Cross Mts., in the area of Wola Morawicka or Morawica villages and are conventionally called the "Morawica Limestone".

Sandstone is the second major rock type used in the St. Anne's church, mainly outside the building. Two of its varieties of the Cretaceous age have been distinguished. The first resembles the Carpathian sandstones from the Istebna Beds. Their occurrences are known in the areas not so distant from Kraków, i.e., situated close to Wadowice, Myślenice, Dobczyce and Brzesko (Peszat, Buczek-Pułka, 1984). The second type represents blocky sandstone from the Lower Silesia (so-called "Quader Sandstone"). This rock has exceptionally good physical and mechanical parameters (Bromowicz et al., 1976), being an excellent building and constructing stone. Such a material occurs in the areas of Radków, Żerkowice, Rakowiczki or Wartowice villages. Petrographic investigations indicate Żerkowice as a place of origin.

A contemporary stone decoration in the form of epitaph plaques should not been overlooked. The stones, namely white marble and red granite, are imports. The white Jurassic limestone may come from the Italian province of Massa Carrara and is known as the Bianco Carrara marble. In turn, the red granite is macroscopically similar to the Capao Bonito granite from the Sao Paulo Province in Brazil and is traded under the same name.

\section{Summary}

The St. Anne's basilica in Kraków is one of more beautiful Baroque sacral objects in Poland. Its substantial artistic value results from a rich stucco decoration and magnificent "Florentine" mosaics, but also from rich and attractively used decorative stones. The stones have been thoroughly selected considering two aspects: their differentiated but - at the same time - harmonised colours used in various decorative elements, and their suitable adapted stonework surface quality. The masonry mastery can be particularly seen in the floor of the church, which shows diversified patterns and coloration in various parts, giving in this way a unique, three-dimensional impression.

Both the decorative and construction stones that can be identified in the church are Polish rock materials, although currently not quarried; thus, they represent a historic value. Therefore, a diversified, not only historical and architectural but also geological view of the St. Anne's collegiate is a worthy proposal for the visitors to the church. It is even more important as the collegiate has been included into several tourist routes, such as "The University Route" and the route "In the Footsteps of John Paul II".

The paper has been prepared within the framework of statutory research grant No. 11.11.140.562 at the Faculty of Geology, Geophysics and Environment Protection, AGH University of Science and Technology in Kraków.

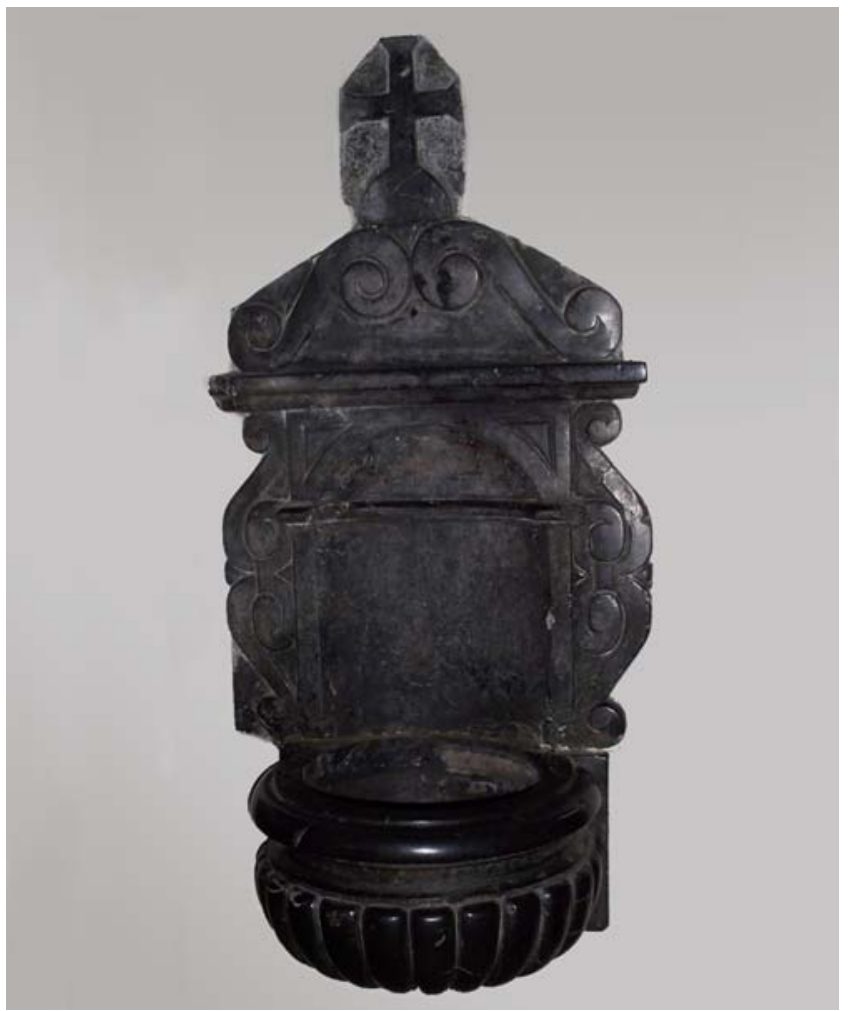

Fig. 11. A stoup made of the black Dębnik Limestone, phot. M. Florczyk $\bullet$ Kropielnica z czarnego wapienia dębnickiego, fot. M. Florczyk

\section{Streszczenie}

\section{Kolegiata św. Anny w Krakowie jako obiekt geoturystyczny}

\section{Monika Florczyk, Anna Smoleńska}

Kraków to miasto o wyjątkowym znaczeniu historycznym, które ma bardzo wiele zabytkowych budowli, a w tym szczególnie cennych z uwagi na bogactwo architektoniczne. Do jednych z piękniejszych barokowych obiektów sakralnych w Krakowie można zaliczyć kościół kolegiacki p.w. św. Anny, związany z Uniwersytetem Jagiellońskim, a przez księdza kardynała Karola Wojtyłę nazwany akademickim sanktuarium. Położony jest w dzielnicy I Stare Miasto, przy ulicy św. Anny, która pierwotnie kończyła się przy murach miej- 
skich (Baszta Rusznikarska) furtą Żydowską, zwaną też furtą św. Anny. W XIV wieku należała do dzielnicy żydowskiej i stąd ulica ta była nazwana Żydowską. Obecną nazwę ustalono pod koniec XV wieku (Ormicka, 2003).

Kraków znajduje się w obrębie Wyżyny Krakowskiej, której tektonika miała wpływ na ukształtowanie jego terenu (Tyczyńska, 1976). Wapienne wzgórza o charakterze zrębów budują skały jurajskie, stanowiące główny materiał budowlany obiektów zabytkowych Krakowa.

Dzisiejszy kościół jest trzecią budowlą stojącą na tym miejscu. Pierwotny był drewniany i spłonął w 1407 roku. Na jego miejscu król Władysław Jagiełło zbudował nowy. Świątynia ta stanowiła centrum religijnego kultu oraz świętowania wszystkich uroczystości zarówno miasta, jak i Akademii Krakowskiej. Jednak jako kościół akademicki była ciasna i dlatego rozpoczęto starania o jej przebudowę (Bukowski, 1903). Patronat nad nowym projektem objął Tylman z Gameren, architekt pochodzenia holenderskiego. Kościół św. Anny wybudowany jest w stylu barokowym (Klein, 1913) z wyjątkowo bogatym wnętrzem obfitującym w malowidła, rzeźby oraz reliefy (Rożek, 1995). Wygląd kolegiaty odwzorowany jest z projektu kościoła San Andrea Della Valle w Rzymie. Różnica pomiędzy nimi polega na tym, że w kościele krakowskim od frontu dodano dwie wieże oraz że prezbiterium ma ścianę prostokątną, a nie półokrągłą, jak ma to miejsce w kościele w Rzymie (Fig. 1). Reszta planu oraz wewnętrzna konstrukcja ścian nie różni się niczym od siebie (Klein, 1909).

Kościół św. Anny usytuowany jest w rzucie podłużnym, na planie krzyża łacińskiego będącego symbolem chrześcijaństwa. Wymiar wertykalny, czyli belka pionowa, oznacza zjednoczenie nieba i ziemi, natomiast wymiar horyzontalny - belka pozioma oznacza zjednoczenie ludzi ze wschodu i zachodu. Kolegiata jest trójnawową bazyliką z transeptem. Ma czteroprzęsłową nawę główną, a po bokach znajdują się połączone ze sobą kaplice z przedsionkiem, stanowiące nawy boczne (Mossakowski, 1965). Ma sześć kaplic przy nawie głównej (Fig. 2). Idąc od wejścia po lewej stronie, są to kaplice: św. Sebastiana, św. Katarzyny Aleksandryjskiej, św. Piotra w Okowach, a po prawej stronie: św. Józefa, Niepokalanego Poczęcia Najświętszej Marii Panny i św. Jana Chrzciciela. W lewym ramieniu transeptu znajduje się kaplica Adoracji św. Krzyża, natomiast w prawym konfesja św. Jana Kantego. Nad nawą krzyżową znajduje się wielka kopuła w rzucie o kolistym kształcie. Jest ona wzorowana na kopule kościoła świętych apostołów Piotra i Pawła w Krakowie. Rolę wykonawcy i dozorującego architekta przy tym projekcie pełnił Baltazar Fontana (Klein, 1909).

W barokowym kościele św. Anny zastosowano licznie kamień w konstrukcji budowli, a także do licznych motywów zdobniczych, przedstawień rzeźbiarskich i reliefów. Użyto go na zewnątrz kościoła między innymi na schodach, w okładzinie cokołu, kolumnach, pilastrach, portalach, w tympanonie, w obramowaniach okien, tablicach epitafijnych oraz w ogrodzeniu. Kamieniem wyłożono również podwórko między kolegiatą a zabudowaniami kościelnymi.

Schody prowadzące do kolegiaty (Fig. 3) wykonane są z kredowego piaskowca ciosowego, którego badania petrogra- ficzne wskazują na pochodzenie ze złoża Żerkowice. Podobne informacje podają Natkaniec-Nowak i Świgoń (2004). Okładzinę cokołu w południowo-wschodniej części kościoła stanowi drobnoziarnisty piaskowiec istebniański wieku kredowego (Fig. 3), natomiast w elewacji północno-zachodniej w dolnej części wapień jurajski, a w górnej drobnoziarnisty piaskowiec istebniański (Fig. 4). Od strony wejścia do świątyni widoczne są pionowe kolumny, rozmieszczone po dwie z prawej i lewej strony głównego wejścia do świątyni oraz płaskie pilastry ustawione przy ścianie (Fig. 5). Każdy trzon kolumn składa się z trzech ciosów piaskowcowych o przekroju koła i spoczywa na profilowanych bazach, a od góry kolumny zamknięte są dekoracyjnymi głowicami wyrzeźbionymi w piaskowcu istebniańskim. Bazy kolumn i pilastrów wykonane są z regularnie obrobionych prostokątnych ciosów wapienia jurajskiego. W fasadzie kolegiaty występują trzy portale: główny (Fig. 6) oraz dwa boczne, będące jednym z piękniejszych jej elementów architektonicznych. Zbudowane są w kształcie stojących prostokątów. Główny jest zakończony dodatkowo od góry tablicą, którą otaczają skręcone fragmenty przerywanego przyczółka (Majewski, 1993). Do wykonania portali użyto kilkunastu ciosów wapienia jurajskiego pochodzącego z Grodziska koło Skały, a w progach zastosowano plamkowy wapień z Morawicy. Do budowy natomiast nadproży w portalach bocznych wykorzystano ponadto różowe wapienie dewońskie pochodzące z Chęcin. Nad portalem głównym znajduje się tympanon o kształcie trójkąta równobocznego, w którego środku umieszczone jest „Oko Opatrzności”, a na szczycie krzyż na prostokątnym postumencie. Do jego wykonania użyto kilkunastu ciosów wapienia jurajskiego i drobnoziarnistych piaskowców istebniańskich. Obramowania okien w fasadzie południowej są półkoliste nad portalem środkowym, a kwadratowe nad portalami bocznymi. Wszystkie są z drobnoziarnistego piaskowca istebniańskiego. Do elementów ozdobnych fasad zaliczyć należy tablice epitafijne z czarnego wapienia dębnickiego.

Kościół św. Anny od strony północno-zachodniej, czyli od Plant, jest ogrodzony dwudziestoma pachołkami, które połączone są ze sobą za pomocą łańcuchów. Materiałem użytym do ich wyrzeźbienia był jasnożółty drobnoziarnisty piaskowiec istebniański. Podwórko mieszczące się między elewacją wschodnią kościoła a zabudowaniami kościelnymi zostało wyłożone brukiem wapiennym, stosowanym co najmniej od XIV wieku w Krakowie do nawierzchni ulic i placów (Rajchel, 2008). Stanowią go bryły wapienia jurajskiego o wielkości od $5 \mathrm{~cm}$ do $30 \mathrm{~cm}$ o nieregularnych i nieforemnych kształtach, które są ułożone blisko siebie.

Kamień znajdujący się we wnętrzu kolegiaty znakomicie łączy wszystkie pomieszczania oraz nadaje im dekoracyjny charakter. Odpowiednio dobrany rodzaj materiału o wspaniałych walorach zdobniczych, stanowiących zespół cech makroskopowych, które wynikają z jego barwy, tekstury, struktury i zdolności do przyjmowania faktury kamieniarskiej, daje możliwość podziwiania niepowtarzalnie zestawionych elementów, tworzących wspaniałe wzory.

Posadzka jest najbardziej wyróżniającym się kamiennym elementem kolegiaty (Fig. 7). Jej wspaniałe wzornictwo opracował Tylman z Gameren. Projektując, kierował się „sztuczką” polegającą na złudzeniu optycznym, przy jedno- 
czesnym zestawieniu kontrastujących barw (Gomoliszewski, 1957). Tylman z Gameren, tworząc wzór posadzki, bazował na prostych figurach geometrycznych oraz na kontrastujących barwach elementów kamiennych, co powodowało, że jedne figury wydawały się większe od drugich. O wyborze kamienia z uwagi na barwę decydował projekt, a ze względu na rodzaj - dostępność jego w najbliższej okolicy. Każdy wzór w posadzce został oddzielony pasem płytek kamiennych o szerokości 20-30 cm oraz długości $25-70 \mathrm{~cm}$, wykonanych z czarnego wapienia dębnickiego (Fig. 8a). W nawie głównej posadzka na całej długości od wejścia do transeptu została ułożona w ten sam wzór, a mianowicie jeden jego element składa się $\mathrm{z}$ pięciu płytek kamiennych. W środku wzoru jest kwadrat o wymiarach $30 \times 30 \mathrm{~cm}$ wykonany z kremowego wapienia jurajskiego, a dookoła ułożone są cztery sześciokątne płytki kamienne z czarnego wapienia dębnickiego (Fig. 8b). Całość tworzy niepowtarzalny efekt przestrzennego spojrzenia na kościół.

Posadzkę transeptu od nawy głównej oddziela pas w kształcie gwiazd (Fig. 8c). Wzór ten ułożony jest z rombów o wymiarach przekątnych $40 \mathrm{~cm}$ i $23 \mathrm{~cm}$. Gwiazdę tworzy sześć elementów z kremowego wapienia jurajskiego, które oddzielone są czarnym wapieniem dębnickim. Motywem przewodnim transeptu na szerokości nawy głównej jest wzór ułożony w kształcie krzyża za pomocą kwadratów o boku $28 \mathrm{~cm}$ i ściętych rogach wykonanych $\mathrm{z}$ czarnego wapienia dębnickiego i mniejszych kwadratów o boku $13 \mathrm{~cm} \mathrm{z} \mathrm{brązo-}$ wego wapienia bolechowickiego (Fig. 8d).

W centralnym miejscu krzyża znajduje się koło o średnicy $80 \mathrm{~cm}$, które wpisane jest w kwadrat o wymiarach $160 \times 160 \mathrm{~cm}$. Elementy te wycięto z kremowego wapienia jurajskiego, natomiast pozostałe wypełnienie stanowi czarny wapień dębnicki. Motyw krzyża dzieli posadzkę na cztery części oddzielone od niego pasem prostokątów $(30 \times 15 \mathrm{~cm})$ wyciętych z brązowego wapienia bolechowickiego. W każdej części płytki są w kształcie rombów o wymiarach przekątnych $38 \mathrm{~cm}$ i $22 \mathrm{~cm}$, które ułożone ukośnie dają efekt promienistego krzyża. Wykonane są z czarnego wapienia dębnickiego oraz brązowego wapienia bolechowickiego (Fig. 8e).

Posadzka lewej nawy bocznej rozpoczyna się w przedsionku wzorem ściętych na rogach kwadratów o boku $22,5 \mathrm{~cm}$, wyciętych z kremowego wapienia jurajskiego i mniejszych kwadratów o boku $9 \mathrm{~cm} \mathrm{z}$ czarnego wapienia dębnickiego (Fig. 8f). Przejście do kaplicy św. Sebastiana zostało wykonane z czarnego wapienia dębnickiego. Wzorem dominującym w obrębie tej kaplicy są gwiazdy ułożone z rombów o wymiarach przekątnych $40 \mathrm{~cm}$ i $23 \mathrm{~cm}$. Każdą gwiazdę tworzy sześć elementów z kremowego wapienia jurajskiego, które oddzielone są czarnym wapieniem dębnickim (Fig. 8g). W kolejnym przejściu do kaplicy św. Katarzyny Aleksandryjskiej znajdują się figury w kształcie rombów o wymiarach przekątnych $31 \mathrm{~cm}$ i $18 \mathrm{~cm}$, które zostały ułożone naprzemianlegle $\mathrm{w}$ trzech rzędach o przeciwnych kierunkach z kremowego wapienia jurajskiego i czarnego wapienia dębnickiego (Fig. 8h). W omawianej kaplicy posadzkę tworzą płytki rombowe o przekątnych $31 \times 18 \mathrm{~cm}$ w trzech kontrastujących kolorach, dających efekt przestrzennie ułożonych sześcianów (Fig. 8i). Zastosowany materiał to: czarny wapień dębnicki, różowy wapień z Chęcin oraz kremowy wapień jurajski. Przejście do kaplicy św. Piotra w Okowach ułożone jest z gwiazd. Na każdą gwiazdę przypada sześć rombów o przekątnych $31 \mathrm{~cm}$ i $18 \mathrm{~cm}$, wykonanych z brązowego wapienia bolechowickiego, które oddzielone są kremowym wapieniem jurajskim (Fig. 8j). Posadzka omawianej kaplicy ma wzór, na który składają się równoległoboki wapienne o odmiennej kolorystyce: brązowy wapień bolechowicki i czarny wapień dębnicki oraz kwadrat wykonany z kremowego wapienia jurajskiego. Łączne ich ułożenie daje efekt przestrzennie występujących prostopadłościanów (Fig. 8k). Przejście do kaplicy transeptu św. Krzyża jest takie samo jak w nawie głównej. Wzór tworzą dwa rzędy gwiazd z kremowego wapienia jurajskiego oddzielone czarnym wapieniem dębnickim. W obrębie kaplicy św. Krzyża posadzkę ułożono w karo, czyli na przemian czarne wapienie dębnickie i kremowe wapienie jurajskie o wymiarach $30 \times 30 \mathrm{~cm}$ (Fig. 81).

Przechodząc do prawej nawy bocznej, dokładnie do kaplicy transeptu św. Jana z Kęt, można zauważyć na posadzce ten sam wzór i rodzaj użytego materiału jak w poprzednio opisanej kaplicy. Przejście do kaplicy św. Jana Chrzciciela oraz posadzka w jej obrębie jest analogiczna do posadzki w kaplicy św. Piotra w Okowach. Kolejne przejście do kaplicy Niepokalanego Poczęcia NMP wykonano w taki sam sposób jak przejście między kaplicą św. Katarzyny Aleksandryjskiej i św. Piotra w Okowach. W obrębie kaplicy Niepokalanego Poczęcia NMP ułożenie płytek kamiennych jest identyczne jak w kaplicy św. Katarzyny Aleksandryjskiej. Różnica jedynie ukazuje się w odmiennej kolorystyce. Użyty materiał kamienny to: czarny wapień dębnicki, brązowy wapień bolechowicki oraz kremowy wapień jurajski. Następne oddzielenie między kaplicami Niepokalanego Poczęcia NMP i św. Józefa jest takie samo jak między kaplicami św. Jana z Kęt i św. Jana Chrzciciela. Posadzkę w obrębie kaplicy św. Józefa wyłożono analogicznie jak w kaplicy św. Jana Chrzciciela. Jedynie różni się kolorystyką. Równoległoboki wykonano z czarnego wapienia dębnickiego oraz kremowego wapienia jurajskiego, natomiast kwadraty z brązowego wapienia bolechowickiego. Ostatnie już przejście z tej kaplicy do przedsionka dekoruje kamień ułożony w formie nadal powtarzającego się w tej nawie motywu gwiazd. Romby tutaj wycięte są z czarnego wapienia dębnickiego, a oddzielone rombami kremowego wapienia jurajskiego. Posadzka prawego przedsionka nawy bocznej jest natomiast analogiczna do posadzki w lewej nawie bocznej.

W dolnej części murów kościoła, od strony wewnętrznej, znajduje się cokół o wysokości $30 \mathrm{~cm}$ wykonany z wapienia jurajskiego z widocznymi fragmentami buł krzemiennych.

Kaplice w kościele św. Anny są bogate w dekorację sztukatorską, ale kamień w nich zastosowany podkreślił jeszcze bardziej ich wspaniały wygląd. Na szczególną uwagę zasługuje zespół dekoracji kaplicy pod wezwaniem św. Jana z Kęt we wschodnim ramieniu transeptu kolegiaty. Można tu podziwiać ogromne, kręcone kolumny o wysokości około $12 \mathrm{~m}$, które posłużyły jako postumenty pod cztery figury świętych Janów: Jana Chrzciciela, Jana Ewangelisty, Jana Chryzostoma i Jana Damasceńskiego. Przywiezienie ich do miasta spowodowało 
rozebranie części muru miejskiego, gdyż nie mieściły się w bramie (Rożek, 2007). Wykonane są z wapienia jurajskiego, prawdopodobnie pochodzącego z łomów bł. Salomei (Bukowski, 1903). Sarkofag świętego Jana z Kęt dźwigają figury personifikujące cztery wydziały Akademii Krakowskiej. Są nimi: Teologia - z prawej strony sarkofagu i Filozofia z przodu części lewej oraz Prawo z prawej i Medycyna z lewej części tylnej. Po bokach u dołu umieszczono postacie czterech doktorów kościoła: św. Augustyn i św. Grzegorz z lewej strony, a św. Ambroży i Hieronim z prawej strony (Rożek, 2007). Natomiast na mensie ołtarza ustawione jest popiersie św. Jana Kantego wykonane z marmuru karraryjskiego.

Naprzeciwko mauzoleum św. Jana Kantego, w zachodnim ramieniu transeptu został wzniesiony ołtarz św. Krzyża z rzeźbioną Pietą i św. Janem Ewangelistą. Na wysokich cokołach wspierają się ustawione pilastry, a na nich zasiadają postacie aniołków. Kamień użyty do dekoracji kaplicy widać w konstrukcji mensy, jej bocznych ścianach oraz stopniach wykonanych z czarnego wapienia dębnickiego. W cokołach baz zastosowano zlepieniec zygmuntowski, natomiast płasko rzeźbiona pieta oraz rzeźbiarska dekoracja wykonana jest ze stiuku.

W pozostałych bocznych kaplicach przeważa kremowy wapień jurajski, który zastosowano w mensach, cokołach i bazach pilastrów, a także z niego wykonano stopnie. Ponadto występują elementy z brązowego wapienia bolechowickiego - czołowa płyta mensy ołtarzy św. Piotra, św. Katarzyny i św. Krzyża, ze zlepieńca zygmuntowskiego - czołowa płyta mensy przy ołtarzu św. Jana Chrzciciela oraz z wapienia dębnickiego - podstawy kolumn w kaplicy p.w. Niepokalanego Poczęcia NPM.

Tablice epitafijne w liczbie około 30. umieszczone są na ścianach bocznych i filarach nawy poprzecznej. Przeważnie są one z XIX wieku i wykonane głównie z czarnego wapienia dębnickiego, kilka z samego wapienia pińczowskiego, a także z elementami wapienia z Paczółtowic. W nielicznych tablicach można spotkać wapień pińczowski stanowiący obramienie czarnego wapienia dębnickiego. Za wyjątkowej wartości dzieło uważane jest epitafum poświęcone Juliuszowi Słowackiemu. Sygnowane jest przez Edwarda Stehlika, a medalion rzeźbiony przez Władysława Oleszczyńskiego (Adamczewski, 1992). Późniejsze tablice pochodzą z końca XX wieku: z czerwonego granitu (Fig. 9) upamiętnia Jerzego Ciesielskiego, przyjaciela i współpracownika Karola Wojtyły, gdy był wikariuszem w kościele św. Floriana w Krakowie, a z marmuru karraryjskiego (Fig. 10) jest darem Ojca Świętego Jana Pawła II dla księdza prałata Władysława Gasidły (Rożek, 2007).

Godny uwagi przy zwiedzaniu kolegiaty jest pomnik Mikołaja Kopernika, znajdujący się w arkadzie transeptu sąsiadującej z prezbiterium kościoła. Wykonany został w latach 1822-1823 według projektu i z fundacji ks. Sebastiana Sierakowskiego przez Jana Nepomucena Galliego (Adamczewski, 1992). Figura astronoma, odlana $z$ brązu, stoi na dużym postumencie odkutym w czarnym wapieniu dębnickim.

Kropielnice w kościele św. Anny umieszczone są w kruchcie kolegiaty oraz przy wejściach bocznych. Wiszą na ścianach, a ich kształt przypomina kielich (Fig. 11). Są wykona- ne z czarnego wapienia dębnickiego, który dekorują widoczne liczne szczątki organiczne oraz białe żyłki kalcytowe.

Kamienne elementy rzeźbiarskie wykonane są z wapienia pińczowskiego. Należą do nich między innymi latarnie kopuł nad kaplicami św. Katarzyny Aleksandryjskiej i Niepokalanego Poczęcia NMP (Natkaniec-Nowak, Świgoń, 2006) oraz figura Chrystusa wisząca na krucyfiksie.

Materiał kamienny zastosowany do budowy i wystroju kolegiaty jest głównie pochodzenia krajowego, a jedynie we współczesnej dekoracji (dwie tablice pamiątkowe) użyto kamienia zagranicznego. Rodzaj kamienia świadczy o tym, że wydobywano go głównie ze złóż znajdujących się w niedalekiej odległości od Krakowa.

Najczęściej stosowanymi materiałami do dekoracji kościoła są „marmury” krakowskie i kieleckie, określane też jako świętokrzyskie. Do nich zalicza się dewoński „marmur” dębnicki i bolechowicki. Pierwszy z wymienionych należy do najstarszych skał wyłaniających się na powierzchni w pobliżu Krakowa. Jego wychodnie znajdują się w okolicach Dębnika (Zaręczny 1891, 1953). „Marmur” bolechowicki pochodzi z rejonu Gór Świętokrzyskich, a najbardziej znane miejsce jego eksploatacji to kamieniołom w Bolechowicach. Trzeci wapień dewoński użyty w elementach dekoracyjnych kolegiaty określany jest jako „marmur Różanka”, zwany jest też „marmurem” chęcińskim vel zelejowskim (Rajchel, 2005) od występowania w grzbiecie góry Zelejowej koło Chęcin. Należy do grupy „marmurów” świętokrzyskich, które mają charakter brekcji tektonicznej. Odznacza się wspaniałą kolorystyką, ale z powodu trudności wydobywania dużych bloków był stosowany głównie w formie intarsji. Należy do skał o najstarszych tradycjach eksploatacji. W literaturze opisywany jest głównie jako marmur grzbietu Zelejowej, okolic Miedzianki, Ołowianki, Zawady i Kowali (Czarnocki, 1958). „Marmur Różanka” jest bardzo podobny kolorystycznie do karbońskiego „marmuru” z Paczółtowic w okolicy Krakowa. Jednak informacja zawarta w dzienniku budowy opisana w pracy księdza Kracika (2003) wskazuje na pochodzenie materiału z okolic Chęcin. Do grupy „marmurów” kieleckich zaliczany jest też zlepieniec zygmuntowski, popularnie zwany „zygmuntówką”, który niewątpliwie jest najbardziej dekoracyjną polską skałą architektoniczną. W nielicznych miejscach kościoła św. Anny można go łatwo zidentyfikować po pięknej plamistej barwie brunatnoczerwonej. Najbardziej znanym miejscem pozyskiwania tej skały jest kamieniołom „Zygmuntówka” położony na stokach Czerwonej Góry leżącej na północ od Chęcin, w obrębie synkliny gałęzicko-bolechowickiej, w pobliżu drogi Kraków-Kielce.

Kolejną skałą węglanową jest wapień jurajski, który znalazł zastosowanie zarówno na zewnątrz, jak i wewnątrz kolegiaty. Biała odmiana drobnodetrytyczna, występująca głównie w bruku podwórka kościelnego, pochodzi najprawdopodobniej z historycznych już kamieniołomów: „Za Torem”, znanego również pod nazwą „Łom Libana”, znajdującego się poniżej kopca Krakusa albo „Tetynka” usytuowanego na Skałkach Twardowskiego. Innymi prawdopodobnymi miejscami pozyskiwania tego materiału mogły być też łomy znajdujące się w rejonie Tyńca, Liszek, Mydlnik czy też Zabierzowa. Nieliczne konkrecje krzemienne w wapieniu 
występującym w cokole wewnątrz kolegiaty świadczą, że pochodzi on z odmiany skalistej, gruboławicowej. Płaskie, skalcyfikowane gąbki krzemionkowe obserwowane na spiralnych kolumnach i bazach przy konfesji św. Jana Kantego, a także na portalach wejściowych do kolegiaty, sugerują, że wykonane zostały z biohermalnego wapienia skalistego. Jedynym miejscem jego występowania są łomy „błogosławionej Salomei”, które znajdowały się na tzw. Grodzisku, przy drodze z Ojcowa do Pieskowej Skały (Holcer, Krajewski, 2001).

Inną odmianą, mającą dużo mniejszy udział w wystroju architektonicznym kościoła, są wapienie, które charakteryzują się występowaniem ciemniejszych plamek określanych jako tuberoidy. Ich pochodzenie można wiązać z okolicami Gór Świętokrzyskich, gdzie w okolicy Woli Morawickiej lub Morawicy występują pod potoczną nazwę „wapień morawicki".

W dekoracji architektonicznej w nieznacznym stopniu został użyty wapień pińczowski, mający matową, ziemistą fakturę, co w zestawieniu ze skałą polerującą się podkreśla jeszcze bardziej jej dekoracyjność. Wapień ten występuje w paśmie wójczo-pińczowskim w rejonie Pińczowa, Bogucic, Wałcza, Szczaworyża i Kikowa oraz w okolicach Chmielnika. Należy do grupy surowców skalnych wykorzystywanych już w X wieku, a pod koniec XII wieku stosowano go w wielu romańskich budowlach sakralnych.

Drugim rodzajem skały użytej w kościele św. Anny głównie na zewnątrz są piaskowce wieku kredowego. Jedne z nich wykazują podobieństwo do piaskowców karpackich $\mathrm{Z}$ warstw istebniańskich. Ich wystąpienia znane w pobliżu
Krakowa znajdują się w okolicach Myślenic i Dobczyc (Peszat, Buczek-Pułka, 1984). Historycznym już miejscem wydobycia piaskowca jest kamieniołom w Borzęcie koło Myślenic, skąd najprawdopodobniej pochodzi surowiec zastosowany w kolegiacie. Inne piaskowce wieku kredowego są piaskowcami ciosowymi z Dolnego Śląska. Odznaczają się on wyjątkowo dobrymi parametrami fizyczno-mechanicznymi (Bromowicz, et al., 1976), przez co doskonale sprawdza się jako surowiec budowlany i konstrukcyjny. Materiał ten mógł pochodzić z kamieniołomów w okolicach Radkowa, Żerkowic, Rakowiczek czy Wartowic. Badania petrograficzne autorek wskazały na piaskowiec z Żerkowic.

Do współcześnie wykonanych płyt epitafijnych użyto materiału zagranicznego, którym jest biały „,marmur karraryjski”, pochodzący z włoskiej prowincji di Massa Carrara i znany pod nazwą Bianco Carrara oraz czerwony granit wykazujący podobieństwo makroskopowe do granitu Capao Bonito z prowincji Sao Paulo w Brazylii.

Kamień budowlany i dekoracyjny kolegiaty ukazuje polskie surowce skalne, które w większości znane są z historycznych miejsc eksploatacji. Można je zatem podziwiać tylko w obiektach budowlanych. Zwrócono szczególną uwagę na dekoracyjność tego kamienia i sposób jego eksponowania zwłaszcza, że opisywana budowla jest często odwiedzana, gdyż znajduje się na trasie kilku szlaków turystycznych takich jak Szlak Uniwersytecki oraz Szlak Śladami Jana Pawła II.

Pracę wykonano w ramach badań statutowych nr 11.11.140.562, prowadzonych na Wydziale Geologii, Geofizyki i Ochrony Środowiska Akademii Górniczo-Hutniczej w Krakowie.

\section{References (Literatura)}

Adamczewski, J., 1992. Kraków od A do Z. Krajowa Agencja Wydawnicza, Kraków.

Bromowicz, J., Gucik, S., Magiera, J., Moroz-Kopczyńska, M., Nowak, T.W., Peszat, C., 1976. Piaskowce karpackie, ich znaczenie surowcowe i perspektywy wykorzystania. Zeszyty Naukowe AGH, Geologia, 2/2,

Bukowski, J., 1903. Krótka wiadomość historyczno-artystyczna o kościele św. Anny w Krakowie. Wydawnictwo Kraków, Kraków.

Czarnocki, J., 1958. Surowce mineralne w Górach Świętokrzyskich. Surowce Skalne. Prace Geologiczne, 5/3, Prace Państwowego Instytutu Geologicznego, 21.

Gomoliszewski, J., 1957. Kościół św. Anny w Krakowie. Dokumentacja geodezyjno-inwentaryzacyjna. Państwowe Przedsiębiorstwo Wydawnictw Kartograficznych. Warszawa.

Holcer, Z., Krajewski, M., 2001. Wykorzystanie górnojurajskich wapieni biohermalnych jako materiału zdobniczego w XVII-wiecznym budownictwie sakralnym. Geologia (kwartalnik AGH), 27: 2-4.

Klein, F., 1909. Akademicki kościół św. Anny w Krakowie. Studium Architektury. Rocznik Krakowski XI: 51-64.

Klein, F., 1913. Barokowe kościoły Krakowa. Rocznik Krakowski XV (15): 97-204.

Kracik, J., 2003. Wspaniałe Bogu wystawione dzieło, jak w Krakowie kościół św. Anny budowano. Wydawnictwo św. Stanisława BM archidiecezji krakowskiej.

Majewski, M., 1993. Dokumentacja konserwatorska: konserwacja fasady południowej kościoła akademickiego św. Anny w Krakowie. Kraków.

Mossakowski, S., 1965. Charakterystyka i geneza formy architektonicznej kościoła św. Anny w Krakowie. Rocznik Krakowski XXXVII, 37: 37-61.

Natkaniec-Nowak, L., Świgoń, A., 2004. Surowce skalne użyte do budowy i wystroju architektonicznego kolegiaty p.w. Św. Anny (cz. II). Świat Kamienia, 2 (27): 28-31.

Peszat, C., Buczek-Pułka, M., 1984. Własności fizyczno-mechaniczne piaskowców istebniańskich. Geologia (kwartalnik AGH), 10/1: 5-34.

Rajchel, J., 2005. Kamienny Kraków. AGH Uczelniane Wydawnictwa Naukowo-Dydaktyczne. Kraków.

Rajchel, J., 2008. Zabytkowe bruki Krakowa. Nowy Kamieniarz, 2: 76-80.

Rożek, M., 1995. Krakowskie sanktuaria: Cracovia sacra, czyli przewodnik po krakowskich sanktuariach. Kraków.

Rożek, M., 2007. Święte miejsca Krakowa altera Roma. Wydawnictwo WAM. Kraków.

Ormicka, U., 2003. Kraków w 3 dni. Wydawnictwo Sport i Turystyka MUZA SA. Warszawa.

Tobiasz, M., 1973. Fortyfikacje dawnego Krakowa. Wydawnictwo Literackie. Kraków.

Tyczyńska, M., 1967. Rzeźba i budowa geologiczna terytorium miasta Krakowa. Folia Geographica, series geographica - physica A, 1: 9-30.

Zaręczny, S., 1891. Mapa geologiczna krakowskiego okręgu. Atlas Geologiczny Galicyi. Komisja Fizjograficzna Akademii Umiejętności. Kraków.

Zaręczny, S., 1953. Atlas geologiczny Galicji. z. 3. Wydawnictwo Geologiczne. Warszawa.

Websites:

http://www.flickr.com 